\title{
ECONOMIC VALUATION FOR WATER SUPPLY FROM MERAPI VOLCANO NATIONAL PARK (CASE STUDY: KALI KUNING SUB WATERSHED)
}

\author{
Ayu Diyah Setiyania ${ }^{a}$, Charlotte de Fraiture ${ }^{\mathrm{b}}$, Robiyanto H. Susanto ${ }^{\mathrm{c}}$, Annelike Duker $^{\mathrm{d}}$ \\ ${ }^{a}$ Program Double Degree Integrated River Lowland and Coastal Development Management and Planning, \\ Sriwijaya University and UNESCO-IHE, Jl. Padang Selasa, Palembang \\ ${ }^{b}$ Water Science Engineering-Land and Water Development Department, UNESCO-IHE, Westvest 7, 2611 AX Delft, \\ Netherlands \\ ${ }^{c}$ Program Pasca Sarjana Ilmu Lingkungan, Universitas Sriwijaya, Jl. Padang Selasa, Palembang \\ ${ }^{d}$ Water Science Engineering-Land and Water Development Department, UNESCO-IHE, Westvest 7, 2611 AX Delft, \\ Netherlands
}

\begin{abstract}
The Merapi Volcano National Park (MVNP) is developed based on particular considerations such as protecting ecosystem or preserving certain species. Management of national park will not succeed unless the communities surrounding park support the park itself. However, it will be challenging because the park was established through a 'top-down' process. Therefore, it is important to ensure that the surrounding communities are able to derive benefit economically from the park, especially environmental services such as water supply. The goal of this study is to estimate the economic value for water supply from MVNP with Kali Kuning Sub Watershed as the study case. The economic valuation is estimated based on three different scenarios of land use maps: 2015's (deforestation), 2025's (afforestation) and extreme condition which is grassland (without national park). The economic value is approached by market price for water use value. Lastly, cost and benefit analysis based on several scenarios (deforestation, afforestation and 'without national park') is implemented. The study shows that afforestation scenario presents the highest economic value from water supply for the surrounding communities as well as the downstream communities.
\end{abstract}

Keywords: economic valuation, environmental services, water supply, national park

(Diterima: 28-07-2016; Disetujui: 03-12-2016)

\section{Introduction}

An ecosystem in Merapi Volcano was established as a national park in 2004 by Ministry of Forestry Decree No 134/Menhut-II/2004 due to its role in the ecosystem. During the establishment process of the Merapi Volcano National Park (MVNP), there is a misunderstanding between the authority of the MVNP and the community surrounding the national park. This problem is because the surrounding village inhabitants utilize the forest resources in the park as grazing land, firewood source, water source, sand mining, and pine resin production according to the result of the social economic survey (MVNP, 2011). Meanwhile, the Law 5/1990 and Law 41/1999 state that the people are not allowed to retrieve those kinds of utilization anymore. Therefore, the people rejected the establishment of the park. In other words, the locals thought that the park was no longer to give any benefit economically for them.

Although the main purpose of national parks establishment is to protect the ecosystem and all ecological processes inside, people can still derive the benefit from those areas. The national parks give a huge number of environmental services to human life beyond the park boundary especially in water services which are an essential part for human life. It is true that ecosystem functions are discussing habitat, biological or system properties or process, but ecosystem goods and services are referred to the benefit that human gets from the ecosystem function (Costanza, et al., 1997). Costanza (1997) also calculated the value of environmental services in varies ecosystem in the world including tropical forest in Indonesia. It was estimated that tropical forest in Indonesia had more than US \$ $10,000 \mathrm{ha}^{-1}$ year $^{-1}$.

In addition, the national parks with their specific ecosystem are not only able to support biodiversity and biological functions but also to benefit ecosystem services (ES) that are socially valuable (Boyd and Wainger, 2003). Further, the benefits of the protected areas spread over their boundaries, so the protected areas can be considered as sustainable development and economic strategies to promote these benefits (Mulongoy and Gidda, 2008) and the ecology system service supports the human directly and indirectly (Costanza et al., 1997).

Even though it is understood that protected areas have an important role in supporting ecosystem service, protected areas are a lack of support from others stakeholders such as local government, surrounding communities and private sectors who often oppose rather than contribute in protected areas management (Midora and Anggraeni, 2006). Generally, the community around the national park do not think that they 
get benefit from the existence of the conservation areas.

Meanwhile, the success key of the national parks management relies on the stakeholders' contribution to the parks. It is possible to the stakeholders including the surrounding communities disregard to the conservation efforts if they do not get the benefit. Therefore, it is necessary to ensure that the stakeholders around the parks, particularly the communities, become the beneficiaries (MacKinnon et al., 1986). It is also stated by Pattanayak (2004) that the contribution to the watershed protection and conservation relies on the net advantages presented by the watershed itself.

Therefore, it is important to realize the ecosystem change and to value ES economically (Bingham et al., 1995) because a better understanding of economic value can be useful for the decision making. Even Boyd and Wainger (2003) stated that there is a huge potential but the mostly unexploited role of environmental services valuation in regulatory decision making.
The objective of this paper is to estimate the economic value for water supply from MVNP with Kali Kuning Sub Watershed as the study case. This objective can be accomplished by understanding some specific objectives which are to define the water use from Kali Kuning sub watershed, to quantify total economic value of the water supply in the national park, and to understand the link between economic value and ecosystem change (in this paper is land use change).

\section{Methods}

This research was conducted in Kali Kuning sub watershed in MVNP on September 2015 to February 2016 (Figure 1a, 1b and 1c). The study areas were limited in villages abstracting water from Kali Kuning sub watershed which are Hargobinangun, Umbulharjo and Kepuharjo Village.

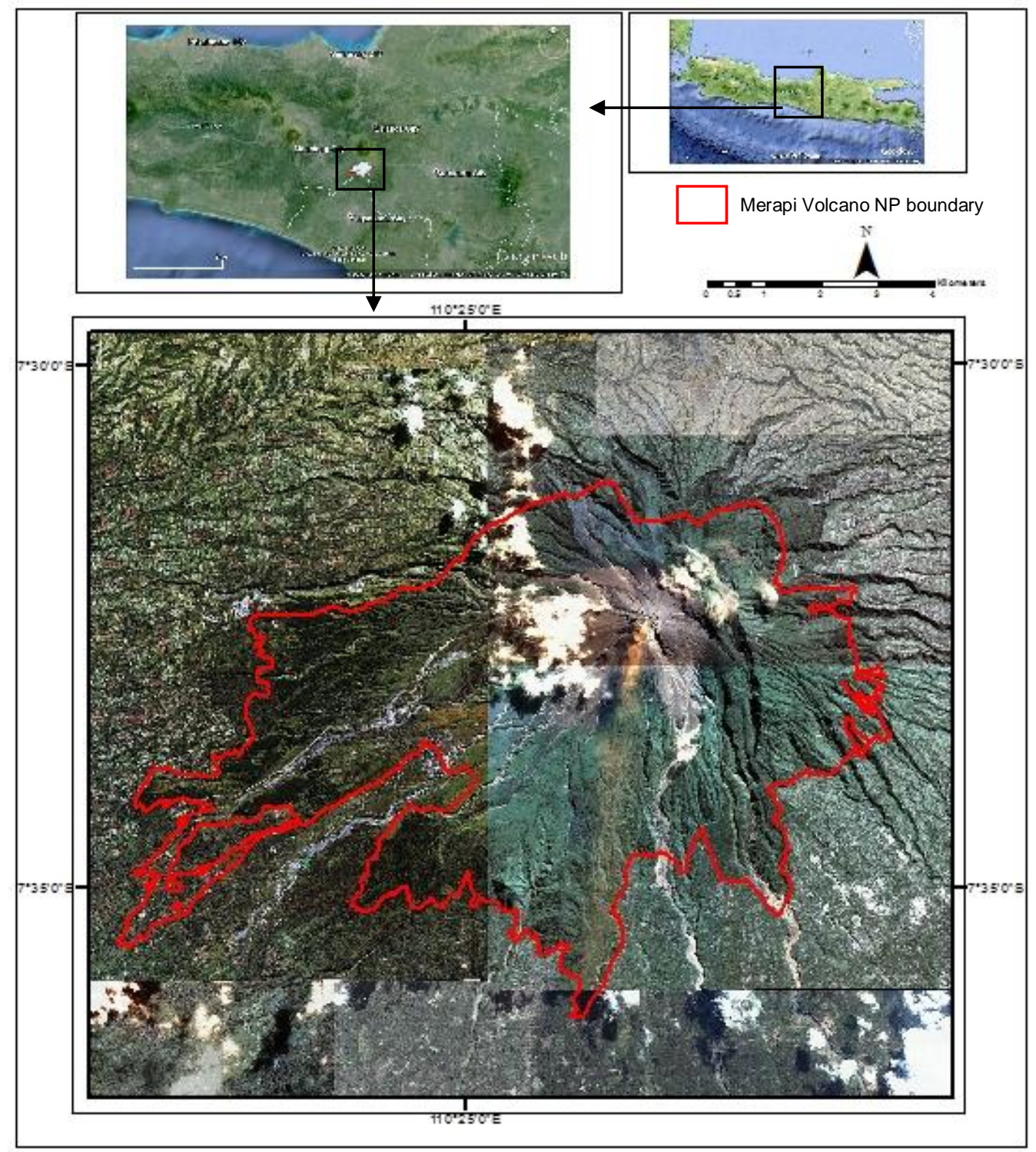

Figure 1a. Boundary of Merapi Volcano National Park. 


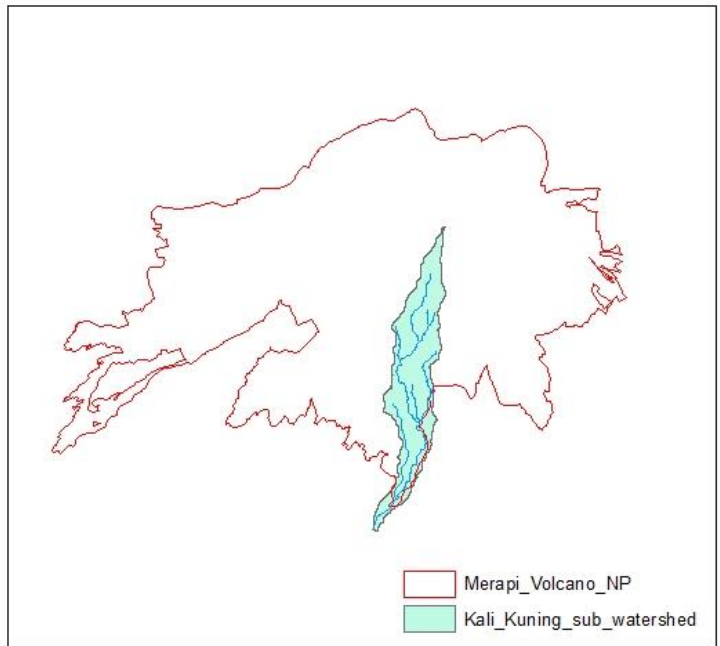

Figure 1b. Kali Kuning sub watershed (study area) in Merapi Volcano National Park.

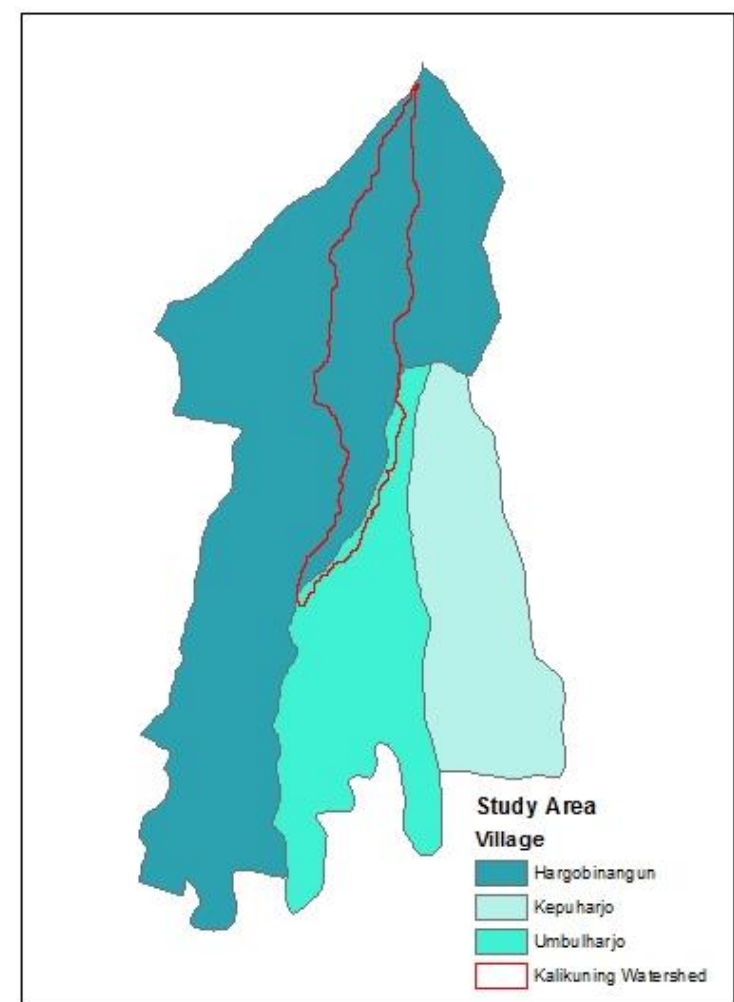

Figure 1c. Villages that abstract water from Kali Kuning sub watershed.

The primary data contain field observation to find out the general condition of the study area. The collected data are the utilization of the water from the Kali Kuning sub watershed in order to identify the direct value of the water. The water use in the study area can be categorized as three groups which are drinking water for the downstream areas like Yogyakarta City and Sleman Regency, drinking water for the habitant in surrounding villages and irrigation. Data of economic valuation were collected by deep interview with the respondents, and then it was validated by focus group discussion (FGD). The data are also collected by interviewing and discussing with a formal and informal organization such as Village Drinking
Water Management Organization, Water Users Association, local government, drinking water companies, and Farmers Association. The data was collected in those three villages on September to October 2015. All the collected data was analyzed to calculate the economic value of water estimating based on market price.

The secondary data was collected from institutional document such as field report from MVNP, regular report from Energy, Water and Mineral Resources Agency of the Sleman Regency and document from local government and organizations. Other data was derived from scientific report such as scientific paper and thesis. All data was used to figure out the ecosystem change and to estimate the impact of its change. The impact of land use change was estimated by Setiyani (2016) using Soil Water Assessment Tool (SWAT).

The primary and secondary data was used to estimate economic value for water supply in different scenarios. Those land uses are 2015's land use or known as deforestation scenario, 2025's land use or known as afforestation and grassland or called as without national park scenario. The 2015's land use is understood as deforestation scenario because most of the forested area was damaged due to volcano eruption in 2010. The 2025's land use is predicted land use based on MVNP's restoration plan. However, the grassland is an extreme condition where all the park does not exist completely change to be grassland for grass production. This condition was assumed based on the highest pressure to the park as grass production in order to support communities' livelihood as dairy farmers. The land use scenarios can be seen in Figure 2 and Table 1. The economic value is understood by applying cost and benefit analysis in each scenario.

\section{Result and Analysis}

\subsection{Water Use}

It is understood that the water supply from the park can be categorized based on water utilizations and users. First, the water is used as drinking water for the downstream communities. It is managed by the drinking water company like Perusahaan Daerah Air Minum (PDAM) Tirta Darma, PDAM Tirta Marta, Perusahaan Daerah (PD) Anindya Argajasa Kaliurang. Second utilization is drinking water for the locals or communities surrounding the park. It is managed by local organizations such as Organisasi Pengelola Air Bersih or local organization for drinking water (OPAB) Umbularjo, OPAB Tirtogondang, OPAB Pangukrejo and Hunian Tetap or permanent settlement (HUNTAP) Kepuharjo. The last purpose of water from the park is for irrigation water. Irrigation is organized by water users associations in Umbulharjo and Hargobinangun, known as Persatuan Petani Pemakai Air (P3A) Umbulharjo and P3A Hargobinangun. 


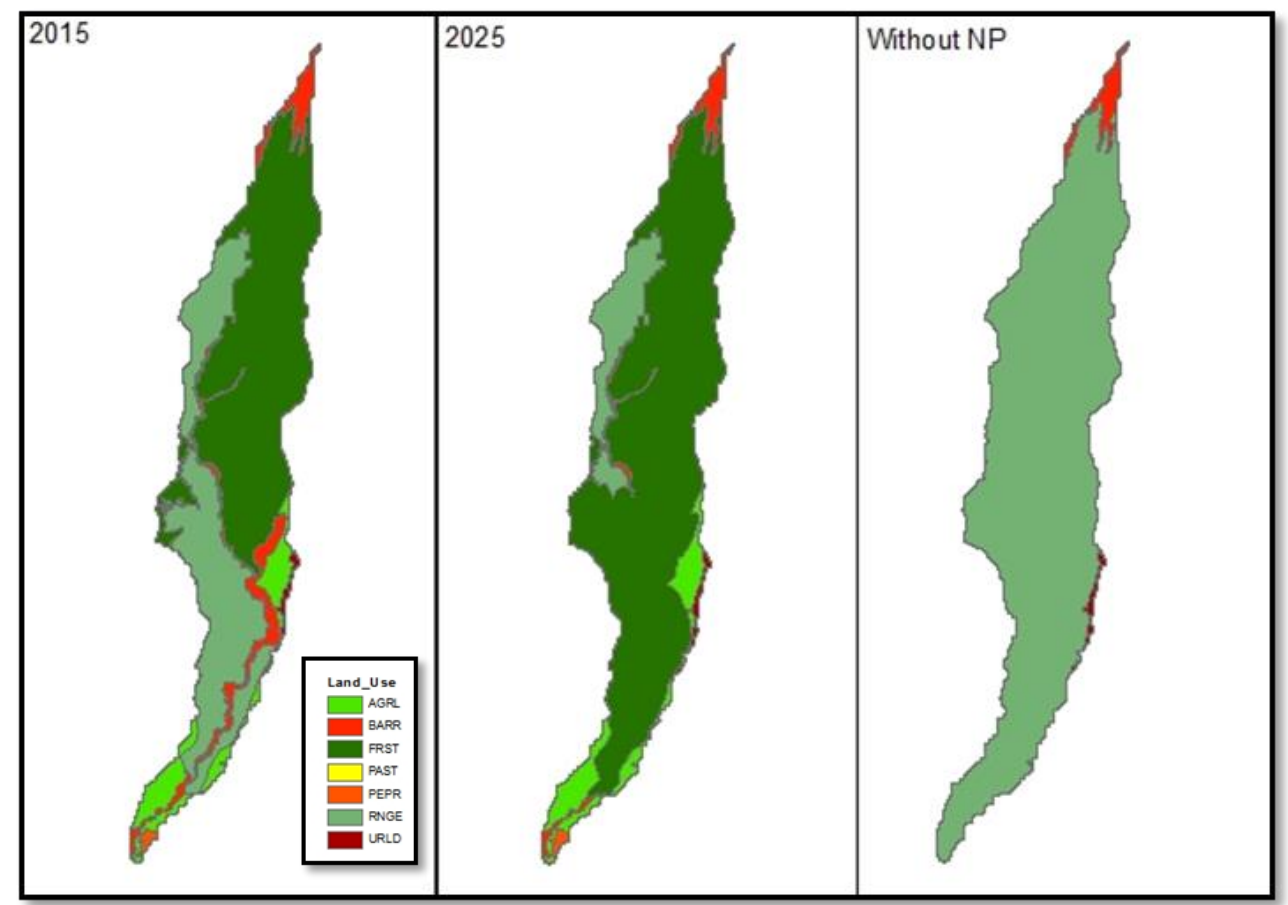

Figure 2. Map of land use scenarios in 2015 (deforestation), 2025 (afforestation) and without national park (grassland)

Table 1. Land use scenarios in 2015 (deforestation), 2025 (afforestation) and without national park (grassland)

\begin{tabular}{|c|c|c|c|c|c|}
\hline \multirow{2}{*}{ Land cover code } & \multirow{2}{*}{ Land cover description } & \multirow{2}{*}{$\begin{array}{l}\text { Land Use } \\
\text { (LU) code }\end{array}$} & \multicolumn{3}{|c|}{ Percentage of area } \\
\hline & & & 2015 & 2025 & No NP \\
\hline Agriculture & Grass (planted) & PAST & 0 & 0 & 0 \\
\hline Bare Soil & Bare soil & BARR & 8 & 4 & 3 \\
\hline Forest & Mixed forest & FRST & 51 & 78 & 0 \\
\hline Grassland & Range grass & RNGE & 32 & 10 & 96 \\
\hline Irrigated Agriculture & $\begin{array}{l}\text { Green bean and chili } \\
\text { It is assumed as bell pepper (Capsicum } \\
\text { annum) }\end{array}$ & PEPR & $\begin{array}{l}\text { Neglected } \\
\text { (equal to } \\
0)\end{array}$ & $\begin{array}{l}\text { Neglected } \\
\text { (equal to } \\
0)\end{array}$ & $\begin{array}{l}\text { Neglected } \\
\text { (equal to } \\
0)\end{array}$ \\
\hline Mix Garden & $\begin{array}{l}\text { Various crops mix with grass and trees } \\
\text { (general agriculture) }\end{array}$ & AGRL & 8 & 8 & 0 \\
\hline Settlement & Low density settlement & URLD & 1 & 1 & 1 \\
\hline
\end{tabular}

However, there are other stakeholders who have interest in the water supply which are MVNP and local institution. The MVNP as national park authority has interest in ecological flow. It is because the ecological flow is tightly related to remain discharge in the Kali Kuning River. The ecological flow is often used by the wildlife in the park to fill their needs. The local institution is Energy, Water and Mineral Resources Agency of the Sleman Regency, an official agency who manages water allocation for each stakeholder.

The water of Kali Kuning sub watershed is distributed based on Environmental Impact Assessment published by Energy, Water and Mineral Resources Agency of the Sleman Regency in 1999 (Figure 3). However, the current situation is totally different because the drinking water companies abstract more water. The actual water abstraction is clearly explained in Figure 4. The companies abstract $48 \%$ of water while they should only derive $35 \%$ of water. In other words, the water demand does not meet with water allocation. The high amount of water demand is dominated by water companies that serve downstream areas. Their customers are households and industries in downstream. This amount is predicted to increase year by year due to increasing population and economic growth.

The local communities are suffered from over exploitation by water companies. It is because the water abstraction for irrigation is decreased from $50 \%$ to $28 \%$. It leads to water scarcity regarding irrigation especially in dry season. Meanwhile, most of the local rely on agriculture and dairy cattle for their lives. In addition, those two businesses are tied tightly with water availability. 


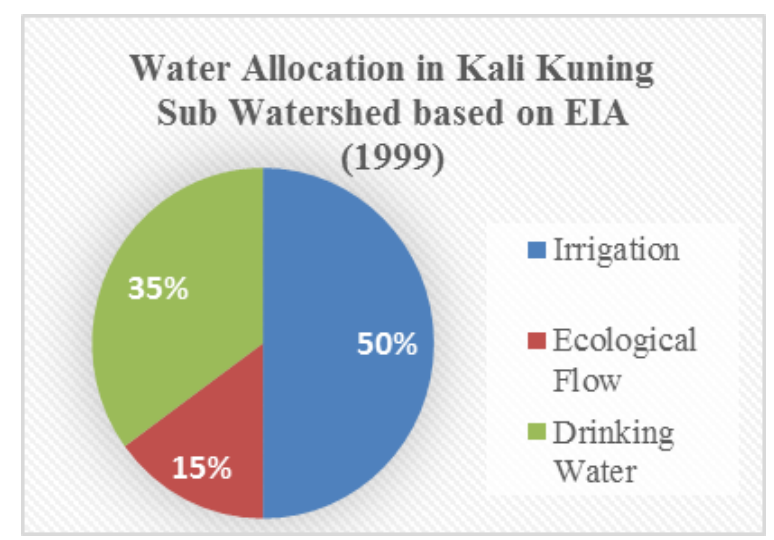

Source: Environmental Impact Assesment (1999)

Figure 3. Water allocation in Kali Kuning Sub Watershed.

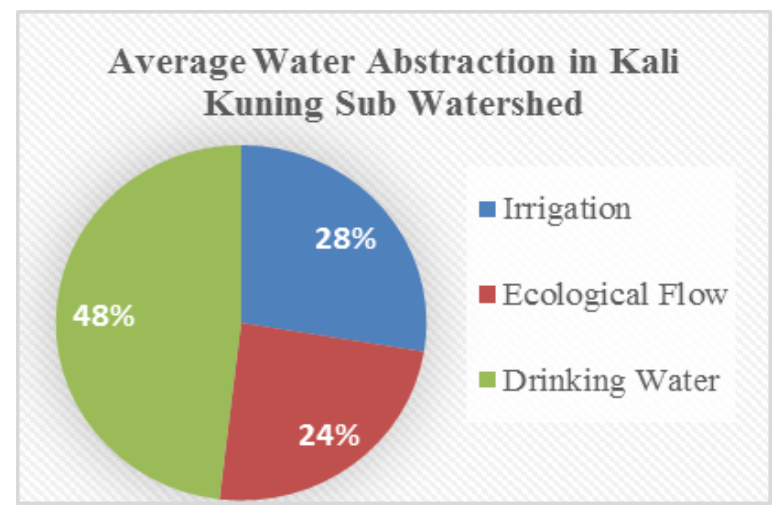

Source: Calculation based on average water abstraction from monthly report of Energy, Water and Mineral Resources Agency of the Sleman Regency (2006-2015)

Figure 4. Average water abstraction in Kali Kuning Sub Watershed.

\subsection{Economic Value of Water Supply}

The economic value from water supply was calculated differently based on water uses which are drinking water for downstream communities, drinking water for surrounding areas and irrigation water. Economic value of drinking water was estimated using two different market prices due to different market. Drinking water for the downstream communities are calculated based on market price which is declared by the drinking water companies (both of PDAM). However, the market price for the drinking water in surrounding communities is approached using the highest price in the three different villages. It was assumed that the highest price is the level of willingness to pay (WTP) from water users. Meanwhile, the irrigation water is computed using crop yield, dairy production and water trading. It is because the local use the irrigation water to irrigate dry land agriculture with chilli and green bean as main crop, to grow grass for their dairy cattle, to fill water services (drinking and cleaning) of dairy cattle and to trade the water to the hotels. Therefore, the irrigation water is approached by production and market price of dry land agriculture and milk and water trading to the hotels.

Therefore, the total economic value of water services from Kali Kuning sub watershed based on drink- ing water, milk production, agriculture yield and water trading. The result of the calculation of the benefit is presented in Table 2. Based on the calculation, it is revealed that the total economic value is approximately USD 1.6 million per year for whole watershed. Furthermore, this benefit is shared among the water users in upstream and downstream.

Compared to the previous studies about economic valuation in the neighborhood national parks, the annual economic value of the Kali Kuning sub watershed shows a lower value than that in Merbabu National Park (MNP). In MNP, the economic valuation was estimated by water supply from Upper Tuntang watershed. The economic value in Upper Tuntang watershed was calculated by a market price in Semarang City which was USD 0.20 per $\mathrm{m}^{3}$. It was known that annual economic value for the water supply is approximately IDR 111 billion or USD 8.2 million (Havid and Suroso, 2013). For the Upper Tuntang watershed, the total economic value for potential water services is USD 3,098/Ha. Meanwhile in Kali Kuning watershed, the economic value is USD $2,516 / \mathrm{Ha}$. Both of value is calculated using same market price which is USD $0.20 / \mathrm{m} 3$. The difference from those watersheds can be caused by the difference amount of water yield.

The different water yield between two ecosystems is possible depending on vegetation coverage (Gumidonga et al., 2014). The difference between those values is in result of water yield in both areas. It is related to land use in both areas. In Upper Tuntang watershed, it is dominated by agriculture, while in Kali Kuning it is dominated by mixed forest. Vegetation has a significant impact to generate surface flow and base flow. The absence of the vegetation cover makes most of the rainfall becomes to be surface flow rather than to be base flow. Further, it is able to decrease the lateral flow and ground water flow. However, the presence of vegetation can direct to higher lateral flow and groundwater flow due to infiltration and percolation.

In addition, economic value of water services in Upper Tuntang was calculated based on water yield; meanwhile, economic value of water services in Kali Kuning is estimated based on water abstraction. It is possible that the economic value of water services in Kali Kuning will be as much as in Upper Tuntang if it includes the water for ecological flow.

\subsection{Impact of Land Use Changes in Water Availability}

It is understood that land use changes contribute significant impact not only to hydrological regimes such as runoff, ground water flow and stream flow. According to Tang et al. (2011), land use changes affect stream flow and sediment yield differently. For instance, conversion from forest to massive use such as agriculture or grassland can be positive in the wet season and be positive or negative in the dry season (Lele, 2009). 
Table 2. Annual economic value based on actual year (2015's land use)

\begin{tabular}{|c|c|c|c|}
\hline Water Use & Annual Production & Market Price & $\begin{array}{l}\text { Economic Value } \\
\text { (USD) }\end{array}$ \\
\hline \multicolumn{4}{|l|}{ Drinking Water } \\
\hline Companies & $5,234,976 \mathrm{~m}^{3}$ & USD $0.20 / \mathrm{m}^{3}$ & $1,046,995$ \\
\hline Communities & $1,119,528 \mathrm{~m}^{3}$ & USD $0.75 / 10 \mathrm{~m}^{3}$ & 48,193 \\
\hline Milk Production & $1,678,224$ liter & USD0.30/liter & 503,467 \\
\hline \multicolumn{4}{|l|}{ Dryland agriculture } \\
\hline Chili & $13,500 \mathrm{~kg}$ & USD $3.00 / \mathrm{kg}$ & 40,500 \\
\hline Green Bean & $4,000 \mathrm{~kg}$ & USD $0.20 / \mathrm{kg}$ & 800 \\
\hline Trade & & & 489 \\
\hline Total Economic Value & & & $1,640,444$ \\
\hline
\end{tabular}

Therefore, it is important to see the effect of the environment changes. It becomes an essential part to figure out what is the cost and what is the benefit due to environment change (Lele, 2009). Thus this study used three different land use scenarios to estimate the economic value of water supply if there are environment changes. Those three different scenarios are deforestation, afforestation and grassland scenario.

Due to the land use change scenarios, it is well understood that in afforestation scenario the water can fulfil the water demand for drinking and irrigation purposes. Afforestation has higher evaporation rates than deforestation and grassland scenario. It makes afforestation scenario produce the least water in the river in the wet period. However, afforestation scenario gives the highest amount of discharge in dry period (Setiyani, 2016).

However, in grassland scenario, the discharge in the river decreases about 3 to $56 \%$ in dry months (Setiyani, 2016), especially in the peak of dry months in August to October. This difference is computed by subtracting the discharge in deforestation scenario (2015's land use) and the discharge in grassland. This decreasing discharge was modelled using SWAT in dry season in dry period in 1997. It means that, the water supply does not accommodate the water demand in dry season under grassland scenario.

These occurrences are caused by vegetation coverage. Vegetation coverage can retain water from rainfall and then transform it as ground water recharge. Grassland is also able to hold water and absorb it as recharge, but it is not as high as forest capability. It is also stated by Gumidonga et al. (2014), he found that the land cover can delayed runoff by infiltration and resulting in the higher base flow.

Land use change from natural forest to other land uses can decrease vegetation coverage that leads to reducing evapotranspiration (Yan et al., 2013). It also declines in infiltration (Gumidonga et al., 2014) due to the reduction in surface roughness and litter (Baker and Miller, 2013). Furthermore, the deforestation scheme increases streamflow (Baker and Miller, 2013; Yan et al., 2013) because most of the precipitation becomes surface runoff rather than infiltration (Baker and Miller, 2013).

In contrast, the reforestation land use scenario has some effects such as an increase in water regulation capacity and a decrease in erosion and soil sedimentation (Lele, 2009). Tomich et al. (2004) stated the similar findings that afforestation and soil conservation are able to decrease peak flow and stormflowand to prevent soil degradation. It can be explained in several previous research by Wang et al. (2015), Yan et al. (2013) and Tang et al. (2011).

It is explained that although the forest both of nature or planted forests demand more water than agriculture and grassland due to the evapotranspiration (Lele, 2009; Nurdin, 2013), still those forests give better infiltration and water storage resulting in high amount in total water yield (Lele, 2009).

\subsection{Impact of Land Use Changes in Economic Value}

Based on the previous discussion in the impact of the land use change, it is understood that there is a change regarding water yield. Therefore, it is important to see the effect of the environment changes such as land use change to the economic value. It can be investigated by understanding who will obtain the benefit and who will lose the benefit due to environment change (Lele, 2009).

A total economic value between two conditions which are under national park (based on 2015's and 2025's land use) and without national park (grassland) can be determined by cost and benefits analysis. The benefit of the water services is estimated based on the water availability for drinking, domesitic uses and agriculture. Meanwhile the cost of water services is predicted by tax and replacement cost to provide the same benefit.

There are different assumption which is used for cost and benefit calculation. For the deforestation and afforestation scheme, the benefit is calculated based on water utilization for all uses. The available water can fulfill all demand. However, in 'without national park' scenario, the discharge in the river decraese. It means there is water scarcity because not all utilization can be filled.

In case of water scarcity in dry months, there is specific policy in order to fulfil drinking water need. The water allocation authority priors the drinking water for drinking water companies regarding the number of beneficiary followed by local beneficiaries and irrigation purposes. Furthermore, to face water shortage, the drinking water companies prefer to find a new water source with required quality rather than to extract ground water or to purify surface water because installing ground water extraction plant and water 
treatment are too expensive. In order to value economic lost regarding the water scarcity, it was calculated based on replacement cost using new instalment cost for new water source to fulfil downstream water demand and purchased water tanker to meet upstream water demand.

Furthermore, the cost analysis in those scenarios are diffrent especially in the 'without national park' scenario. It is because the cost is estimated based on tax and replacement cost. It is related to the water quality in Kali Kuning. The water quality is acceptable as drinking water based on Government Regulation PP 492/Menkes/Per/IV/2010 (Wardani and Purnama, 2012). If there is not enough water in 'without national park' scneario, the drinking water companies should build particular infrastructure to get new water source or to purify the groundwater and the locals should buy water using water tanker. Then, it can be categorized as replacement cost. In this study, the cost is calculated based on installing a new water source. It is because planting a new water intallation in a qualified water source is much affordable than installing water threatment to purify ground water extraction. Meanwhile in afforestation and deforestation scenario, there is no any payment for further water threatment due to water quality. The only cost is the tax for the surface water.

The result of cost and benefit analysis is presented in Table 3. It is obvious that the afforestation scenario contributes the highest economic value. It is followed by deforestation and 'without national park' scenario. The afforestation scenario contributes USD 1.8 million per year to all beneficiaries. Then, the economic value of deforestation scenario is slightly decrease to USD 1.6 million. However, the 'without national park' does not contribute any economic benefit even it loss about USD 230,000 anually. It is because there is no available water for all beneficiaries Therefore the cost to provide the same benefit in two previous scenario is much higher.

However, compared to the previous study, it seems that the result of total economic value is overestimated. The total economic value of water supply and water regulation in rain forest area were about USD 8/ha/year and USD 6/ha/year (Costanza et al., 1997). In addition, the economic value for water supply in Leuseur National Park was approximately USD $300 /$ ha/year in conservation scenario. While, in this study, total economic value for water supply is about USD 2,200/ha/year.
The result of the economic valuation of water forest related service in this study seems overestimated compared to Coztanza et al. (1997) and Beukering at al. (2003) where their result are only about USD 14/ha/year and USD 300/ha/year. It means that the econovic valuation of water services is a kind of tricky bussiness. It might mislead the result because there are overlapping and ambiguity in the service itself (Ojea et al., 2012). In addition, Ojea et al. (2012) explained that overlapping service and ambiguity service causes double counting in economic valuation can be a problem to sort it out in economic valuation. Then, the result can be overestimated or underestimated to the market fluctuation which is price is the result between supply and demand. Meanwhile, in this study, the price based on the supply and demand is neglected because the study applied the same price for each scenario. However, if it compared with another study in the neighbourhood area in Upper Tuntang Watershed in the Merbabu National Park (Havid and Suroso, 2013), it does not show large gap in between. It because both of national park (Merapi Volcano and Merbabu) give similar economic value. The total economic value in, the Upper Tuntang watershed is USD 3,098/ha and the economic value in Kali Kuning watershed is USD 2,516/ha.

The benefit from the national park is distributed among all stakeholders. Obviously, whatever the scenario, local communities gain largest portion of the benefit followed by the drinking water companies which are owned by local government. Beukering, et al. (2003) explained that the highest benefit was gained by the locals followed by the government and private sectors under 'with or without national park' scenarios. He also mentioned that the locals' share grows time by time in conservation scenario.

The result announces that all stakeholders suffer negative consequences from the absence of national park. Drinking water companies need to invest more money in infrastructure. The drinking water companies possibly increase water price for the downstream users. On the other hand, the local communities' share will be decrease time by time, and they have to buy water for drinking water in the same quantity and quality as before. It was predicted as well by Beukering et al. (2003) that the local communities would experience expensive water and the companies will lose money to change distribution system under 'without national park' scenario.

Table 3. Economic value of water supply from MVNP in three different scenarios

\begin{tabular}{|c|c|c|c|c|c|c|}
\hline & \multicolumn{2}{|c|}{$\begin{array}{l}\text { 2015'scenario/ } \\
\text { deforestation (USD) }\end{array}$} & \multicolumn{2}{|c|}{$\begin{array}{c}\text { 2025's scenario/ afforestation } \\
\text { (USD) }\end{array}$} & \multicolumn{2}{|c|}{$\begin{array}{c}\text { Grassland/ without national park } \\
\text { (USD) }\end{array}$} \\
\hline & Cost & Benefit & Cost & Benefit & Cost & Benefit \\
\hline Drinking water & 9,694 & $1,095,188$ & 10,862 & $1,257,104$ & $1,517,856$ & 783,821 \\
\hline Irrigation water & & 545,256 & & 545,256 & & 503,467 \\
\hline Total & 9,694 & $1,640,444$ & 10,862 & $1,802,360$ & $1,517,856$ & $1,287,288$ \\
\hline Net Benefit & & $1,630,750$ & & $1,791,498$ & & $-230,568$ \\
\hline
\end{tabular}




\section{Conclusions}

The main purposes of water supply from MVNP are drinking water for downstream and upstream areas and water for irrigation. This water supply benefit is shared among stakeholders who are downstream communities (Sleman Regency and Jogjakarta City) and local communities (Hargobinangun, Umbulharjo and Kepuharjo Village). However, the management of the beneficiaries are diverse one and another. The drinking water for the downstream is managed by water companies (PDAM), while the drinking water for the locals is managed by local drinking water organizations. In addition, the irrigation purpose is managed by water users association. Furthermore, the land use change gives significant impact in water availability and economic value of water. The afforestation with the largest forested area gives the highest amount of economic value (USD 1.8 billion) compared with other scenario which is deforestation (USD 1.6 billion). However the grassland scenario will lose USD 230,568 due to replacement cost for a new instalment regarding a new water source. In addition, both upstream and downstream communities have the highest share of the benefit, but they also suffer if there is land use change from national park to grassland.

\section{Acknowledgements}

This paper is partly taken from my thesis of with title 'Economic valuation for water services from Merapi Volcano National Park, Indonesia Case Study: Kali Kuning sub watershed.' I acknowledge Prof. Charlotte de Fraiture, Prof. Robiyanto H. Suseno, Annelieke Duker, M.Sc., Ir. P.H.J. Hollanders, and Dr. Shreedhar Maskey for the support and guidance. I appreciate BAPPENAS and Stuned for financing this study. I thank to UNESCO-IHE and Sriwijaya University.

\section{References}

[1] Baker, T. J. and Miller, S. N., 2013. Using the Soil and Water Assesment Tool (SWAT) to assess land use impact on water resources in an East African watershed. Journal of Hydrology, Volume 486, pp. 100-111.

[2] Bingham, G., R. Bishop, M. Brody, D. Bromley, E. T. Clark, W. Cooper, et al., 1995. Issues in ecosystem valuation: improving information for decision making. Ecological Economics 14, pp. 73-90.
[3] Beukering, P. J. H. V., H. S. Cesar, and M. A. Janssen, 2003. Economic valuation of the Leuser National Park on Sumatra, Indonesia. Ecological Economics 44, pp. 43-62.

[4] Boyd, J., and L. Wainger, 2003. Measuring Ecosystem Service Benefits: The Use of Landscape Analysis to Evaluate Environmental Trades and Compensation. Resources for the Future, Washington.

[5] Costanza, R., R. d'Arge, R. D. Groot, S. Farber, M. Grasso, B. Hannon, et al., 1997. The value of the world's ecosystem services and natural capital. Nature 387, pp. 253-260.

[6] Gumidonga, W., T. Rientjes, A. Haile, T. Dube, 2014. Predicting streamflow for land cover changes in the Upper Gilgel Abay River Basin, Ethiopia: A TOPMODEL based approach. Physics and Chemistry of the Earth 76-78, pp. 3-15.

[7] Havid, E. and D. S. A. Suroso, 2013. Valuation of Water Production and Erosion Protection in Upstream of Tuntang Watershed for Payment of Ecosystem Services (In Bahasa). Jurnal Perencanaan Wilayah dan Kota 3 (1), pp. 46-54.

[8] Lele, S., 2009. Watershed services of tropical forest: from hydrology to economic valuation to integrated anaylisis. Environmental Sustainablity I, pp. 148-155.

[9] MacKinnon, J., MacKinnon, K., Child, G., and Thorsell, J., 1986. Pengelolaan Kawasan yang Dilindungi di Daerah Tropika (Tropical Protected Areas Management). Gadjah Mada University, Yogyakarta.

[10] Midora, L. and D. Anggraeni, 2006. Economic Valuation of Watershed Services Batang Gadis National Park, Mandailing Natal, North Sumatra, Indonesia. Conservation International - Indonesia, Jakarta.

[11] Mulongoy, K. and S. Gidda, 2008. The Value of Nature: Ecological, Economic, Cultural and Social Benefits of Protected Areas. Secretariat of the Convention on Biological Diversity, Montreal.

[12] [MVNP] Merapi Volcano National Park, 2011. Report: Socio Economic of Surrounding Merapi Volcano National Park Pasca Volcano Eruption in 2010, Merapi Volcano National Park, Yogyakarta.

[13] Ojea, E., J. Martin-Ortega, A. Chiabai, 2012. Defining and classifying ecosystem services for economic valuation: the case of forest water services. Environmental Science and Policy 19-20, pp. 1-15.

[14] Pattanayak, S. K., 2004. Valuing Watershed Services: Concepts and Empirics from Southeast Asia. Agriculture, Ecosystem, and Environtment 104, pp. 171-184.

[15] Setiyani, A. D., 2016. Economic valuation for water services from Merapi Volcano National Park, Indonesia Case Study: Kali Kuning sub watershed. Thesis. UNESCO-IHE, Delft.

[16] Tang, L., D. Yang, H. Hu, and B. Gao, 2011. Detecting the effect of land-use change on streamflow, sediment and nutrient losses by distributed hydrological simulation. Journal of Hydrology 409, pp. 172-182.

[17] Wang, X. et al., 2015. Assessment of soil erosion change and its relationship with land use/cover change in China from the end of the 1980s to 2010. Catena 137, pp. 256-268.

[18] Wardani, A. E. P. And I. L. S. Purnama, 2012. Evaluasi potensi mata air untuk kebutuhan air domestik di Kecamatan Cangkringan Kabupaten Sleman pasca erupsi Merapi 2010 (Potential spring evaluation for domestic uses in Cangkringan District, Sleman Regency) In Bahasa. Jurnal Bumi Indonesia 1(3), pp. 229-309.

[19] Yan, B., N. Fang, P. Zhang, Z. H. Shi, 2013. Impact of land use change on watershed stream flow and sediment yield: An assessment using hydrologic modelling and partial; least squares regression. Journal of Hydrology 484, pp. 26-37. 